\title{
Felkért hozzászólás \\ „Michéli Erika, Fuchs Márta, Szegi Tamás, Csorba Ádám, Dobos \\ Endre, Szabóné Kele Gabriella: A diagnosztikus szemléletben megújított hazai talajosztályozási rendszer: alapelvek, felépítés, osztályozási szabályok" \\ címü vitaanyagához (2018.10.10).
}

\author{
TóTH Gergely \\ Pannon Egyetem, Georgikon Kar, Talajtani és Környezetinformatikai Tanszék, \\ Keszthely \\ Agrártudományi Kutatóközpont, Talajtani és Agrokémia Intézet, Budapest \\ (Beérkezett: 2019.10.25.; Elfogadva: 2019.10.29.)
}

\section{Kivonat}

A Magyar Talajtani Társaság honlapján MıCHÉLi és munkatársai (2018) által vitaanyagként közreadott osztályozási javaslat koncepcióját, szerkezetét, osztályozási kritériumait, eljárását és nevezéktanát több szempontból megvizsgálva, valamint összevetve a hatályos hazai talajosztályozással, külföldi nemzeti rendszerekkel és a nemzetközi talajkorrelációs rendszerrel számos kérdés merül fel. Ezek megválaszolása csupán a talajtani szakemberek széles körének bevonásával lehetséges. Az alábbi koncepcionális és technikai kérdések megválaszolása szükséges:

1. Mennyiben tekinthető a javasolt rendszer nemzeti osztályozási rendszernek tekintettel arra, hogy annak eljárása szinte teljességgel benne foglaltatik a nemzetközi korrelációs rendszer (WRB) osztályozási eljárásában és a javasolt hazai és a WRB osztályozási egységei is nagyon nagyfokú hasonlóságot mutatnak?

2. Érdemes-e a jelenlegi hazai talajosztályozás által használt hierarchikus struktúrát (vele a fótípus-típus-altípus-változat rendszert) feladni, és ezzel a társtudományok és a gyakorlati alkalmazások számára a hagyományos, egyszerü értelmezési lehetőségeket lecserélni egy olyan újra, amiben már a második osztályozási szint is több száz talajegységet tartalmaz?

3. Mennyire megfeleltethetők a korábbi, az új javaslatban szereplő szempontoktól eltérő felvételezésekből származtatott, meglévő osztályozási adatok az új elképzelések szerinti rendszernek? Vagyis milyen mértékü az átkonvertálás bizonytalanságából adódó információvesztés, ill. téves besorolás kockázata, ha a meglévő térképi és egyéb adatbázisban szereplő talajokat az új rendszer szerint szeretnénk osztályba sorolni és elnevezni?

4. Mekkora mértékű lehet a megengedett információvesztés, ill. mekkora lehet a téves besorolás kockázata, aminek árán még érdemes teljesen új, a jelenlegi rendszer koncepciójától eltérő megközelítésű és szerkezetü olyan osztályozási rendszert bevezetni, aminek a meglévő talajosztályozási adataink csak (kisebb) részben feleltethetök meg?

Levelezö szerzö: TóTH GeRgely, Pannon Egyetem, Georgikon Kar, Talajtani és Környezetinformatikai Tanszék, H-8360 Keszthely, Deák Ferenc utca 16

E-mail: toth.gergely@georgikon.hu 
5. A talajtani terminológia - egyes esetekben, alapjaiban való újrafogalmazása mennyiben szolgálja a tudományos és a gyakorlati megértés érdekeit?

6. Hogyan oldhatók fel a hagyományos elnevezések és a javasolt rendszer között konfúziót teremtő nevezéktani ellentmondások (pl. a barnaföldek esetén)?

7. A nemzetközi példák alapján lehet-e olyan alternatívája a talajosztályozás diagnosztikus szemléletủ megújitásának, ami megtartja a genetikai talajosztályozás szerkezetét és fötípusait?

8. Érdemes-e a meglévő osztályozási konvenciókat elvetni evvel megbontva ezzel a talajosztályozási hagyományokat, akár a nemzetközi megfeleltetés könnyítése, akár egyéb okok miatt? Konkrét példaként egy agyagos réti talaj esetében mi a fontosabb, az agyagosság (duzzadó agyag tartalom) vagy a réti jelleg?

9. Javasolható volna-e a nemzetközi referencia bázis (WRB) használatának ajánlása minden új talaj-felvételezés ill. osztályozás során, a nemzeti (genetikus) rendszerrel párhuzamosan?

Az alábbiakban a kérdések felvetésének hátterét kívánom megvilágítani.

A kérdések megválaszolása mellett javaslom a vitaanyagban bemutatott rendszert a WRB-vel szerkezetében és tartalmában összevetni. Egy ilyen összevetéssel eldönthető lehet, hogy a genetikai talajosztályozási rendszerünk mellett érdemes-e egy, a WRB-vel szerkezetében, osztályozási kulcsában és osztályaiban nagyfokú egyezést mutató új rendszert is a gyakorlati használat számára javasolni, esetleg érdemes-e inkább a jelenlegi hatályos rendszerrel (később annak pontosított változatával) párhuzamosan közvetlenül a WRB-t is használni az osztályozás során.

\section{Bevezetés}

Hazai talajosztályozási rendszerünk pontosításának igénye régóta időszerủ és több forrásból is táplálkozik. Tudományos és részben gyakorlati érvek is sürgetik, hogy a genetikai talajosztályozási egységek azokban az esetekben is számszerü értékekkel különüljenek el, ahol a hatályos osztályozási eljárás (MÉM 1989; FÖLDVÁRI ÉS DARAB 1966; STEFANOVITS 1972) ilyen iránymutatásra nem támaszkodhat. Könnyü belátni, hogy a szubjektív elemek kizárása a talajok taxonómiai meghatározásának folyamatából a talajtannak is elemi érdeke. A vizsgált talajobjektum más talajobjektumoktól történő megkülönböztetése, a megkülönböztetésükre használt további vizsgálatok csak pontos definíciók szerint történhetnek. A különböző külföldi talajosztályozó rendszerek szerint osztályozott talajok összehasonlítását is ilyen módon lehet a legnagyobb biztonsággal megtenni. A tudományos megfontolásokon túl a gyakorlati alkalmazások pontosságát és ellenőrizhetőségét is jelentősen növeli az osztályozási információk egyértelmüsége. 
Az alábbiakban foglalom össze a jelenleg használatos talajosztályozás megújításának kereteit:

- Jelenlegi talajosztályozási rendszerünk tudományos alapja a talajképző tényezők és talajfolyamatok, valamint a hatásukra létrejövő talajféleségek tulajdonságainak rendszerszerü értelmezése, struktúráját pedig a rokonság mértékét mutató genetikai kapcsolatok jellege és erőssége alakítja.

- Az elmúlt évtizedek kialakult konszenzusa, hogy a talajféleségek taxonómiai lehatárolásához a szubjektív elemek kizárása érdekében a meglévő rendszert az eddig is meglévő diagnosztikai kritériumok mellett további, akár számszerüen definiált diagnosztikai kritériumokkal kell kiegészíteni, amire elsősorban a téves osztályba-sorolás elkerülése érdekében van szükség.

- A téves osztályba-sorolás az, amikor az egyezö tulajdonságú talajok közül az egy-, vagy több helyen feltártat nem a tulajdonságai által tudományosan meghatározott taxonómiai egységbe tartozónak azonosítanak.

- A jelenlegi, több évtizede szolgáló, talajosztályozási rendszerünkre épül:

○ a tudományos szakirodalom (a talajtani szakirodalmon kívül a vonatkozó agronómiai, erdészeti, természet- és környezettudományi)

o számos gyakorlati alkalmazás (trágyázási szaktanácsadás, talajvédelem, stb.)

○ a ma rendelkezésünkre álló talajinformációk (térképek, adatbázisok) döntő többsége.

\section{Nemzetközi kitekintés}

Az utóbbi évtizedekben kidolgozott, ill. megújított külföldi, nemzeti talajosztályozási rendszerek az egyes taxonómiai egységek diagnosztikai jellemzőkkel leírt kategorizálása alapján állnak (KRASILNIKOV et al. 2009) és ilyen irányban fejlődik a Nemzetközi Talaj Korrelációs Rendszer (World Reference Base for Soil Resources; WRB, IUSS 2006, 2014) is. A környező országok talajosztályozási rendszereit az elmúlt évtizedekben sorra megújították. Jellemzően megmaradtak a korábbi fötípusok, illetve az azokkal egyenértékü átfogó morfogenetikus talaj-kategóriák (KRASILNIKOV et al. 2009). Igaz, néhány esetben (pl. Szlovákiában) új kategóriákat is kialakítottak. A típusok besorolása során elsősorban a pontosabb elhatárolás, másodsorban a WRB-vel való összevethetőség érdekében történtek változtatások, mindenütt kerülve az erőltetett megfeleltetéseket. Ausztriában NeSTROY és munkatársai (2011) rendszere megtartotta a genetikus osztályozást és benne az osztrák csernozjom (Tschernosem) fogalmát és nem változtatta a besorolást a WRB definíciója szerint. Romániában FLOREA és MUNTEANU (2012) rendszere szintén megtartotta a korábbi hierarchikus felépítést és osztályozási egységeket, de előfordult, hogy utóbbiak az új besorolásban altípus szintre kerültek. Nevezéktanában az osztrákhoz hasonló hagyománytisztelet figyelhető meg, vagyis a román rendszertan is megőrizte a csernozjom (Cernoziom) nevet. 
A közelmúltban megújított lett talajosztályozás szintén megtartotta a tradicionális, genetikai rendszertani alapokat, miközben a szelvényleírás és analitika módszereit a nemzetközi gyakorlathoz igazította és a talajkategóriák elhatárolásához határértékeket rendelt (KARKLINS et al. 2009). A nemzeti igények elötérbe helyezése szempontjából figyelemre méltó, hogy miközben a megújult lett klasszifikációban egyaránt podzolnak osztályozott talajok a WRB hat különböző referenciacsoportjába is sorolhatók, addig például a WRB-ben egyöntetüen Histosolnak leírt talajok egyéb tulajdonságaiktól függően a lett osztályozás három legmagasabb szintủ kategóriájából bármelyikbe, illetve azok számos alegységébe sorolhatók. A lett talajosztályozás megújítói ezeket olyan tényként kezelik, ami nem válik hátrányára az új, nemzeti osztályozásuknak (KARKLINS et al. 2009).

Ugyancsak fontos adalék a talajosztályozás megújítási törekvéseihez az a tény, hogy a környező országok (Ausztria, Csehország, Románia, Szlovákia) megújított osztályozási rendszerei egyaránt megtartották a hierarchikus struktúrát (KRASILNIKOV 2009).

Az említett megújított nemzeti osztályozási rendszerek három legfontosabb jellemzöje a helyi igények elötérbe helyezése, a hagyománykövetés és ezen szempontok mellett a rendszertani egységek lehatárolási jellemzőinek pontosabb definíciója. A pontosabb nemzetközi megfeleltetés nincs a leglényegesebb szempontok között, bár mindenütt figyeltek rá.

\section{Áttekintés és vélemény a talajosztályozási rendszerek felépítéséről}

$\mathrm{Az}$ emberi megismerésre kevésbé jellemző a strukturális szemantika igen/nem osztályozása, helyette a prototípuselmélet alapján, a tipikalitási feltételek segítségével megadott központi kategóriák leírását tartják célravezetőnek (FóRIS 2015). A talajtudomány kognitív szemléletủ és ezt a szemléletet érvényesíti a jelenlegi hazai és a legtöbb külföldi nemzeti talajosztályozási rendszer is, amikor a tipikalitási feltételeket használ a főtípusok és alsóbb egységek leírásához. Ebben a koncepcióban egy talaj akkor is beletartozhat az adott rendszertani egységbe, ha nem minden tipikalitási feltétel jellemző rá, vagy ha részben különbözik a talajegység tipikus változatától ${ }^{1}$. A talajosztályozás diagnosztikai szemlélete, ami a strukturális szemantikai megközelítéssel rokon, alkalmazható a tipizált egységekből kiinduló osztályozás során is. Ahogy a „Nemzetközi kitekintés” részben bemutattam, több külföldi példa is mutatja, hogy a diagnosztikai tényezők alkalmazásával is világosan érvényesíthető a kognitív szemlélet.

Az osztályozás szerkezetével és kategóriáinak kialakításával összefüggésben beszélni kell a hierarchikus és a nem-hierarchikus osztályozási megközelítésekröl.

Meglévő hazai rendszertanunk (MÉM 1989; előzményeit lásd még: FöLDVÁRI és DARAB 1966; STEFANOVITS 1972;) hierarchikus rendszer, ami talajgenetikai és

\footnotetext{
${ }^{1}$ Az egyes talajféleségek tipikus változata sok osztályozási rendszerben önálló taxonómiai egység nevében is megjelenik. A magasabb osztályozási egység „központi koncepciójának” több, egymástól bizonyos jellemzőkben eltérő, de főbb jellemzőiben megegyező vagy nagyon hasonló talaj is megfelelhet.
} 
talajföldrajzi alapokon áll. A talajok nem-hierarchikus rendszerezése elméletileg valóban nagyobb szabadságot nyújt a talajváltozatosság egyedi kifejeződésének rokonsági rendszerbe helyezésére, mivel a fontosnak itélt tulajdonságok megnevezésének nagyobb számú kombinációját teszi lehetővé.. Ebből a szempontból tehát esetenként akár jobb megoldást nyújthat a hierarchikus osztályozásnál. A többszintủ rendszerek kialakításában a rokoni kapcsolatokról meglévő ismeretek szisztematikus érvényesítése ugyanakkor - a lokális osztályozási rendszer esetében, amilyen egy nemzeti osztályozás is - érdemben nem csökkenti a helyi talajjellemzők diktálta osztályozási preferenciákból adódó klasszifikációs lehetöségeket.

A hierarchikus rendszerek viszont számos előnnyel is bírnak: az absztrakció több szinten lehetséges, könnyebb érthetőség és memorizálhatóság, valamint az egyszerübb struktúra (MCKENZIE et al 2008). Megjegyzendő, hogy gyakran a nemhierarchikus rendszerekben, pl. a WRB-ben is felfedezhető a rejtett hierarchia (KRASILNIKOV et al. 2009). A fenti okok miatt is, de legalább annyira a hazánkban fellelhető nagytömegü és különböző térbeli és tematikus részletességü archív talajinformációra való tekintettel és a jelenlegi osztályozás más előnyei miatt (pl. szakmai beágyazódottság) is érdemes megtartani a magyar talajosztályozás jelenlegi szerkezetét, a fötípus-típus-altípus-változat-helyi változat hierarchiát. A szerkezet így segítheti a továbbiakban is a talajokról meglévő (genetikai, talajföldrajzi és talajjellemzőket tükrözö) ismeretek többcélú közvetítését, a már meglévő adatok és ismeretek alapján, a hagyományok követésével. Hazai viszonyaink között a fötípusok rendszertani kategóriájának létjogosultsága bizonyított; ez az osztályozási szint biztosítja a talajképződési folyamatok - és az ebből származó számos közvetett talajtulajdonság -, egységes elméleti rendszerbe foglalásának lehetőségét. A talajosztályozási eljárás elméleti alapjainak szilárdsága mellett gyakorlati érvek is indokolják a fötípus megtartását a talajosztályozási hierarchia legfelsőbb szintjén. Egy sor alkalmazás, pl. agronómiai osztályozás, kisléptékü térképek szerkesztése, oktathatóság, társtudományi (ökológia stb.) kapcsolatok mind igénylik a talajok rendszerezésének azt a kevésbé részletes, de logikus és átfogó modelljét, amit a fötípusok-típusok jelenlegi rendszere nyújt.

\section{A vitaanyagban javasolt rendszer alapjellemzőiről}

A talajosztályozás megújítására tett javaslatban bemutatott rendszer:

- a jelenlegi rendszer fötípusai helyett a típusokat helyezi az osztályozás legfelsőbb szintjére;

- 15 talajtípust határoz meg és javasol;

- ezek azonosítása és elkülönítése a korábbihoz részben hasonló, részben új követelmények alapján történik;

- a jelenlegi tisztán hierarchikus rendszer helyett a legfelsőbb szint alatt egy moduláris megközelítést javasol már a második szinten is több száz talajegységgel, amit a harmadik szint változati jellemzői még tovább részleteznek; 
- a diagnosztikus kategóriák definíciói a WRB vonatkozó kategóriáival megfeleltethetők.

\section{Az osztályozási szabályokra és eljárásokra vonatkozó megjegyzések}

Egy ideális osztályozási rendszerben a talajokról jól mérhető jellemzőik alapján egyértelmủen eldönthető, hogy beletartoznak-e egy kategóriába, vagy nem. Erre törekszik minden talajosztályozási rendszer. Kétségtelenül nagy munka, de a hazai talajok összességének rendszertani leírásához nem megkerülhető egy olyan mátrix összeállítása, ami az egyes rendszertani egységek határait pontosan körvonalazza. Egy egyszerü osztályozó kulcs iránymutató lehet, de ennek kizárólagos alkalmazása a gyakorlatban óhatatlanul a fentebb jellemzett prototípus elmélet elvetéséhez vezet, ami az előző részekben vázoltak szerint hátrányokkal jár.

A rokon talajtípusok rendszertani határait az osztályozás valamennyi szintjén úgy kell kijelölni, hogy azok minden irányból világos formában mutassák az elhatárolt talajféleség tulajdonságait a rokon talajféleségekhez viszonyítva is..

$\mathrm{Az}$ osztályba sorolás folyamán (az osztályozási rendszer alkalmazásakor) természetesen elégséges az egyes tulajdonságok szerinti szisztematikus elkülönítés, de az osztályozási rendszer kidolgozásakor és az osztályozási egységek elkülönítésekor a tulajdonság-együttesek által definiált fötípus- és talajtípuskoncepció megfogalmazását érdemes első lépésként elvégezni. Ezt követheti a koncepcionális egységek határainak kijelölése. A határok mindig közös határok, egy, vagy több talajtípus közös határai.

A taxonómiai határok megvonásához a talajtípusra vonatkozó koncepció mellett a terepi és laboratóriumi vizsgálatok eredményei adnak útmutatást. Magyarországon a helyszíni talajfelvételezés eljárását a MÉM (1989) módszerkönyve, míg a laboratóriumi vizsgálatok módszereit számos szabvány (BUZÁs 1988, 1993) határozza meg. Ezek az eljárások sok esetben különböznek a külföldi, ill. nemzetközi módszertanokban meghatározott eljárásoktól (USDA 2004, FAO 2006).

A talajegységek nemzetközi megfeleltetésének feltétele a meghatározásnál alkalmazott módszertanok megfeleltethetősége. A nemzetközi megfeleltetéshez szükséges megvizsgálni, hogy a hagyományos és szabványos magyar eljárások által, amikből hazai adatbázisaink építkeznek, meghatározott tulajdonságok mennyire különböznek a nemzetközi osztályozásban elöírtakkal kapott eredményektől. Az új osztályozási javaslatban, bár a nemzetközi megfeleltetést prioritásként jelöli meg, nincs erre vonatkozó útmutatás. Emiatt, a mérési eljárások és a határértékek különbözőségéből eredően, a javaslat jelen formájában téves megfeleltetési forgatókönyveket is kódol. 


\section{A javasolt osztályozás objektivitásáról}

A szubjektív elemektől mentes, elfogulatlan és pontos osztályozás minden osztályozási rendszer kidolgozóinak törekvése. A mostani javaslat fö motivációja is az, hogy minden esetben kizárható legyen a szubjektív megítélés lehetősége és csak pontosan meghatározható jellemzők képezzék az osztályba sorolás alapját. Olyan jellemzők, amik vagy a terepen, vagy a laboratóriumban minden kétséget kizárólag azonosíthatók, ill. számszerüsíthetők. A feladat nehézségét elsősorban az adja, hogy nem minden esetben határozható meg egyértelmüen az adott talajtulajdonság. Egyes tulajdonságok időbeli változatossága, pl. a mészlepedéké is jelentheti a meghatározás akadályát, ugyanis lehetnek időszakok, amikor a tulajdonság szembetűnő, és amikor kevésbé, vagy egyáltalán nem. Más tulajdonságok, pl. a csúszási tükör felismeréséhez nagy szakértelem (és megtalálásához - nota bene némi szerencse is) szükséges. Vannak olyan jellemzők, pl. az agyaghártya, amik kevésbé kifejlett formái, vagy más eredetủ morfológiai jegyekkel való összetéveszthetősége adhatnak okot vitára, szubjektív állásfoglalásra. Az olyan kritérium, mint pl. a „szerkezete kedvező” szintén lehet szubjektív elem.

$\mathrm{Az}$ objektivitás tekintetében több ponton is elörelép a javaslat a hatályos osztályozáshoz képest, de még mindig vannak kritikus pontok (pl. agyaghártya, csúzsási tükör, mészlepedék, szerkezet), amik a felvételezőre bízzák a döntést. Ezért sem beszélhetünk - meglátásom szerint - teljesen objektív rendszerről. A „központi koncepció” elvetése pedig azt eredményezheti, hogy egy, a terepen nem felismert jellemző regisztrációjának hiánya, vagy téves regisztrációja miatt a talaj nem a legközelebbi rokonaival kerül egy rendszertani egységbe, hanem azoktól kialakulásukban és jellegükben is különbözökkel.

\section{Terminológiai kérdések}

A talajosztályozással szembeni alapvető elvárás, hogy a használt terminológiája megfeleljen a talajtan fogalmi rendszerének. A terminológia segítségével elkerülhetö, hogy különbözö dolgokat ugyanúgy nevezzenek. A talajtani terminológiában az egyes fogalmak jelentése a köznyelvi jelentéstől eltérhet, sok esetben pontosabb jelentéstartalmat kap azáltal, hogy a talajtan fogalmi rendszerén belül használjuk. Mivel a fogalmi rend a tudományos kommunikáció alapja, ezért különösen körültekintően kell eljárni a terminológia területén.

A javasolt talajosztályozási rendszer legtöbb esetben következetesen használja a talajtani terminológiát, új kifejezéseket is alkalmaz (amiket általában a WRB adaptálása révén vezet be), és azokat legtöbbször jól építi a meglévő terminológiába. Ugyanakkor van néhány fogalom, amit kevésbé körültekintően használ. Fogalmi ellentmondásnak tủnik például a „mezőségi talaj” megnevezés, ami alatt a továbbiakban nem egyesítené a mezőségi körülmények között kialakult talajokat. Ugyanis azok, a mezőségi talajok, amik színe nem elég sötét, függetlenül a származásból adódó összes többi jellegtől, amik az egyensúlyi anyagforgalmi típusból adódnak, és amik jellegzetes képződési környezete a füves mezőség, nem 
lennének mezőségi talajoknak nevezhetők. Tehát egy genetikai kategória („mezöségi talajok”) névvel jelölt talajféleségek közül kirekeszti a keletkezésében hasonló, de egyes jellegében atipikus talajokat.

Más okból, de talán még problematikusabb a javaslatban szereplő „barnaföld” elnevezés. Ennél a kategóriánál ugyanis a majd évszázados szemantikai stabilitást mutató „barnaföld” típust kiveszi a barna erdőtalajok kilúgzási kontextusából és a mezöségi jellegü talajokat is barnaföldnek ajánl nevezni. A talajtan fogalmi rendszere ezt a nyelvhasználatot nem engedheti meg, mivel ez nagyon zavaros helyzetet teremtene.

Úgy gondolom, hogy a teljes felhasználói közösség (tudományos és szélesebb alkalmazói réteg) és a néhány fös talajosztályozó tudományos közösség szóhasználatának illeszkednie kell és szerencsésebb lenne, ha a talajosztályozók a hagyományos terminológiát megtartanák (lásd az osztrák példát) és erre építenék az osztályozás szerves fejlődését.

\section{A javasolt rendszer viszonya a hatályos hazai osztályozáshoz}

A javasolt rendszer az osztályozás szerkezetének és koncepciójának fentebb tárgyalt új megközelítésén túl a legmagasabb rendszertani szinten lehatárolt talajegységek (korábban: fötípusok; az új javaslatban: típusok) esetében is jelentős változásokat javasol, a korábbi 9 fötípus helyett 15 típust. Ezek között az antropogén talajok megjelenése régen várt elörelépés és a rendszerbe vonása akkor is feltétlenül üdvözlendő volna, ha az osztályozás megújítása a hagyományos struktúrát követve történne. Egyes diagnosztikai kritériumok bevezetése szintén jól szolgálja a talajokról az egységes gondolkodást és a rendszertani egységek pontosabb lehatárolását is.

Más konvenciók megváltoztatására tett javaslatok esetében gondosan mérlegelni kell ezek létjogosultságát, illetve az esetleges változtatás sokrétủ hatását. $\mathrm{Az}$ „erdőtalaj” és a „réti talaj” konvenciók és velük együtt a talajtan kognitív megközelítésének elvetése, helyettük a WRB-ből a Luvisol (agyagbemosódásos talajok), Vertisol (duzzadó agyagtalajok) és Gleysol (glejes talajok) magyar megfelelöinek beiktatása részletes szakmai vitát tesz szükségessé.. A szakmai vita nem arról szólna, hogy hazánkban ne lennének luvic, vertic vagy épp gleyic talajok, hiszen minden talajtanos ismeri az agyagbemosódást, a duzzadó agyagokat és a glejesedést. A vita alapja, hogy ezeket emeljük-e az osztályozás legfelsőbb szintjén döntő kritériumokká.

Amennyiben ezt elfogadjuk, és WRB mintájára alapjaiban változtatjuk meg az osztályozás szerkezetét és tartalmát, mint ahogy azt az előterjesztés javasolja, úgy számolni kell többek között a meglévő térképi és egyéb információk konverziójának problematikájával is. Azoknak az információknak az átmentéséről van szó, amiknek létrehozása több évtizedes erőfeszítéseket és mai áron több tíz-, vagy százmilliárd forint ráfordítást igényelt.

A vitaanyag javaslatai olyan helyzetet prognosztizálnak, amiben a jelenlegi rendszer osztályozási egységeibe tartozó különböző talajok a javasolt új osztályozás több, gyakran nagyon eltérő osztályozási egységébe kaphatnak új besorolást. Ez 
valamennyi osztályozási egységre igaz, így mintegy „szétszórva” az eddig rokonként leírt talajokat az új taxonómiai egységek között. Ez önmagában is zavart keltene a felhasználók körében, de nem csupán erről van szó. Arról is, hogy a legtöbb esetben nem állnak rendelkezésre olyan adatok, amik valamennyi javasolt diagnosztikai kritériumhoz megfelelők lennének. Így marad a szakértői becslés, ami újra csak szubjektivitással terhelt. (A becslés megbízhatósága csak úgy volna maximalizálható, ha a jelenlegi osztályozási rendszer kategóriáit is kizárólag diagnosztikai kritériumok alapján határolnánk le, ami egyébként egy lehetséges alternatíva a talajosztályozás reformjára.) A megfeleltetések megbízhatósága tehát különösen nagy jelentőségü a meglévő talajadatok szempontjából. Ugyanakkor jelenleg ezekről semmilyen információval, számítással vagy becsléssel nem rendelkezünk. Az új rendszer ebből a szempontból csak úgy validálható, ha legalább a legfontosabb térképi (földminősítési, Kreybig stb.) és egyéb (TIM, MARTHA stb.) adatbázisokon tesztelve megfelelne az információ megörzés fontos kritériumának. Ilyen jellegű összehasonlító munkát a vitaanyag szerzői nem közölnek.

\section{A javasolt rendszer viszonya a nemzetközi korrelációs rendszerhez (WRB)}

A nemzetközi korreláció a belföldi prioritásokhoz képest a legtöbb nemzeti rendszerben másodlagos jelentőségü, de az egyes rendszerek kidolgozói erre a szempontra is figyeltek (a „Nemzetközi kitekintés” részben). Az új javaslat nemzetközi korrelációs rendszerhez való viszonyáról az 1. táblázat ad áttekintést, a részletes összehasonlítást az online melléklet (То́тH, 2019) teszi lehetővé. Az összehasonlítás során a WRB 2006-os kiadását vettük alapul, mert ennek elérhető a magyar fordítása (NOVÁK 2013), ami továbbá a terminológia konzisztenciája szempontjából is fontos. Megjegyzendő, hogy a WRB gyakori (1998, 2006, 2014, 2015) és jelentős változásait nehezen követheti bármelyik nemzeti osztályozási rendszer. Még ha a helyszíni és a laboratóriumi eljárások egységesítése teljes körú is, az egyes rendszertani egységek pozíciója folyamatosan változhat.

Vizsgálataink során azt találtuk, hogy a javasolt új rendszer túlnyomó részt hasonló kritériumokat és rendszertani kategóriákat használ, mint a WRB. Az is megfigyelhetö, hogy a hazai rendszer szinte teljes egészében benne foglaltatik a WRB rendszerében (lásd melléklet: TÓTH, 2019). Az osztályozási (diagnosztikai) kritériumokat és rendszertani határokat tekintve is csak kisebb eltérések figyelhetők meg. Mindezek felvetik a kérdést, hogy nem volna-e célszerübb a vitaanyagban javasolt rendszer helyett inkább közvetlenül a WRB-t használni. Természetesen ezt egy nemzeti osztályozási rendszer mellett volna érdemes megtenni. 


\section{1. táblázat}

A vitaanyagban javasolt rendszer és a nemzetközi korrelációs rendszer (WRB, 2006) viszonyának áttekintése

\begin{tabular}{|c|c|c|c|c|}
\hline $\begin{array}{l}\text { Sor- } \\
\text { szá } \\
\mathrm{m}\end{array}$ & $\begin{array}{l}\text { A javasolt új } \\
\text { osztályozási } \\
\text { rendszer } \\
\text { talajtípusai }\end{array}$ & $\begin{array}{l}\text { WRB (2006) } \\
\text { megfelelője }\end{array}$ & $\begin{array}{l}\text { A javasolt új osztályozás } \\
\text { kritériumainak hasonlósága } \\
\text { a WRB (2006) } \\
\text { osztályozáséval }\end{array}$ & $\begin{array}{l}\text { A javasolt rendszer és } \\
\text { a WRB (2006) részlet- } \\
\text { gazdagságának } \\
\text { viszonya }\end{array}$ \\
\hline 1. & Láptalajok & "Histosols & nagyfokú hasonlóság & a WRB részletesebb \\
\hline 2. & $\begin{array}{l}\text { Antropogén } \\
\text { talajok }\end{array}$ & $\begin{array}{l}\text { Anthrosols } \\
\text { vagy } \\
\text { Technosols }\end{array}$ & $\begin{array}{l}\text { nagyfokú hasonlóság } \\
\text { (Anthrosols és Technosols } \\
\text { kritériumok kombinációja) }\end{array}$ & a WRB részletesebb \\
\hline 3. & $\begin{array}{l}\text { Köves sziklás } \\
\text { talajok }\end{array}$ & $\begin{array}{l}\text { Leptosols } \\
\text { (Lithic) }\end{array}$ & $\begin{array}{l}\text { Lithic Leptosollal szinte } \\
\text { teljes egyezés }\end{array}$ & $\begin{array}{l}\text { a WRB részletesebb } \\
\text { (a hazai javaslatban egy } \\
\text { további kritérium a } \\
\text { kőzet felszíni } \\
\text { megjelenése) }\end{array}$ \\
\hline 4. & $\begin{array}{c}\text { Közethatású } \\
\text { talajok }\end{array}$ & Leptosols & teljes egyezés a WRB-vel & $\mathrm{a} W R B$ részletesebb \\
\hline 5. & $\begin{array}{c}\text { Szolonyec } \\
\text { talajok }\end{array}$ & Solonetz & teljes egyezés a WRB-vel & $\mathrm{a} W R B$ részletesebb \\
\hline 6. & $\begin{array}{c}\text { Szoloncsák } \\
\text { talajok }\end{array}$ & Solonchak & $\begin{array}{c}\text { majdnem teljes egyezés a } \\
\text { WRB-vel }\end{array}$ & $\mathrm{a} W R B$ részletesebb \\
\hline 7. & $\begin{array}{l}\text { Duzzadó } \\
\text { agyagtalajok }\end{array}$ & Vertisols & teljes egyezés a WRB-vel & $\mathrm{a} W R B$ részletesebb \\
\hline 8. & Réti talajok & $\begin{array}{c}\text { Gleysols, } \\
{ }^{1} \text { Chernozems } \\
\text { vagy } \\
{ }^{2} \text { Kastanozems, } \\
\text { Phaeozems } \\
\text { Gleyic } \\
\end{array}$ & $\begin{array}{l}\text { nagyfokú egyezés a WRB } \\
\text { Gleysol csoporttal ill. } \\
\text { „gleyic” talajokkal }\end{array}$ & $\mathrm{a} W R B$ részletesebb \\
\hline 9. & $\begin{array}{c}\text { Karbonát } \\
\text { talajok }\end{array}$ & ${ }^{3}$ Calcisols & $\begin{array}{l}\text { közepes mértékü egyezés } \\
\text { (azonos jellemzők, de } \\
\text { különböző mélységi és } \\
\text { mennyiségi kritériumok) }\end{array}$ & hasonló részletesség \\
\hline 10. & $\begin{array}{l}\text { Mezőségi } \\
\text { talajok }\end{array}$ & $\begin{array}{l}\text { Chernozems és } \\
\text { Kastanozems }\end{array}$ & $\begin{array}{c}\text { nagyfokú egyezés } \\
\text { (a Chernozem és Kastanozem } \\
\text { csoportok kritériumainak } \\
\text { kombinációja) }\end{array}$ & $\mathrm{a} W R B$ részletesebb \\
\hline 11. & $\begin{array}{l}\text { Agyag- } \\
\text { bemosódásos } \\
\text { talajok }\end{array}$ & $\begin{array}{l}\text { Luvisols, } \\
\text { Alisols }\end{array}$ & $\begin{array}{c}\text { közepes szintü egyezés a } \\
\text { WRB-vel }\end{array}$ & $\mathrm{a} W R B$ részletesebb \\
\hline 12. & Homoktalajok & Arenosols & $\begin{array}{c}\text { majdnem teljes egyezés a } \\
\text { WRB-vel }\end{array}$ & $\mathrm{a} W R B$ részletesebb \\
\hline 13. & Barnaföldek & $\begin{array}{l}\text { Calcisols és } \\
\text { Cambisols }\end{array}$ & $\begin{array}{c}\text { majdnem teljes egyezés a } \\
\text { WRB-vel }\end{array}$ & $\mathrm{a} W R B$ részletesebb \\
\hline 14. & $\begin{array}{l}\text { Hordalék- } \\
\text { talajok }\end{array}$ & $\begin{array}{l}\text { Fluvisols, és } \\
\text { Colluvic } \\
\text { Regosols } \\
\end{array}$ & nagyfokú egyezés a WRB-vel & $\mathrm{a} W R B$ részletesebb \\
\hline 15. & $\begin{array}{c}\text { Földes } \\
\text { kopárok }\end{array}$ & Regosols & teljes egyezés a WRB-vel & hasonló részletesség \\
\hline
\end{tabular}




\section{Egyéb megjegyzések}

- A tudományos életben elkerülhetetlen, hogy az egyszerú megértéstől az összetettig, a könnyü vizsgálatoktól a több erőforrást igénylő mérésekig ível a fejlődés. Így van ez a talajtanban, azon belül a talajrendszertanban is. A fejlődéssel párhuzamosan ugyanakkor a kutatók mindig keresik az egyszerübb megoldásokat. A talajosztályozás fejlesztése során is érdemes lehet megvizsgálni, hogy vannak-e olyan lehetőségek, amik a körülményesen és drágán vizsgálható paraméterek helyett könnyebben meghatározhatókkal (esetleg ezek kombinációjával és új struktúrába helyezésével) biztosítják a pontos osztályba sorolást. Megfontolandó, hogy a javaslatban megjelenő újabb, nehezebben vagy költségesen azonosítható diagnosztikai jellemzők kiválthatók-e (esetleg más struktúrában).

- A különböző taxonómiai szintek minősítő jelzői nem egységesen használtak, ami zavarja a megértést.

- A vitaanyagban olyan állítások találhatók, amik részben pontatlanok, részben nem teljesen megalapozottak, vagy amelyek alátámasztására hozott hivatkozásokban nincs az állításra vonatkozó szöveg. Pl. az új talajtípusok bevezetését ,a hazai igények és nemzetközi tapasztalatok alapján” indokolja és ezen igények és tapasztalatok alátámasztására Michéli et al. 2015-ös közleményét hivatkozza. A hivatkozott közleményben azonban nincs kifejtve, hogy mik volnának azok a „hazai igények” és „nemzetközi tapasztalatok” amik az új talajtípusok bevezetését indokolnák.

- A vitaanyag irodalmi hivatkozásokat felsoroló fejezete (11. fejezet) több helyen, angol nyelven jelzi a közlemények eredeti nyelvét (In Romanian, in Czech stb.) vagy például a szerkesztőre utaló rövidítést (ed.) ami miatt az a benyomása az olvasónak, mintha az anyag nem magyar használatra készült volna.

\section{Következtetések és javaslat}

Nagy és fontos munkára vállalkoztak a szerzők, amikor a talajosztályozásunk pontosítását tüzték célul. Jelentős elörelépést értek el bizonyos diagnosztikai kritériumok pontosításában és talajaink taxonómiai távolságának vizsgálatát is elkezdték, ami új elemekkel gazdagította a talajféleségeinkről meglévő ismereteket. A vitaanyagban javasolt osztályozási rendszer azonban formai és tartalmi szempontból is több olyan tudományos és gyakorlati kérdést vet fel, amik miatt a javasolt rendszer jelen formájában nem feltétlenül szolgálná a hazai érdekeket. Jelenlegi formájában aggályosnak tartom a hazai osztályozási hagyományokkal szakító és a WRB-vel nagyfokú hasonlóságot mutató javaslatot „megújított hazai talajosztályozási rendszer” címmel közölni. Legalább is, csak számos kérdés megnyugtató megválaszolása után dönthető el, hogy a vitaanyagban közreadott rendszer megfelel-e azoknak a kritériumoknak, amiket a szakemberek elvárnának egy új, nemzeti osztályozási rendszertől. 
Megítélésem és javaslatom szerint a hazai talajokkal foglalkozó szakemberek széles körének bevonásával érdemes részletesen megvitatni a cikkem elején, annak kivonataként felsorolt koncepcionális és technikai kérdéseket.

\section{Irodalom}

BuZÁS I. (szerk) 1988. Talajvizsgálati módszerkönyv 2., Mezőgazdasági Kiadó. Budapest

BuZÁS, I. (szerk.), 1993. Talaj- és agrokémiai vizsgálati módszerkönyv. 1. INDA 4231. Budapest.

Florea, N. és Munteanu, I. (2012). Sistemul Român de Taxonomie a Solurilor (SRTS), Ed Sitech, Craiova

FóRIS Á. 2015. Osztályozási módszerek a terminológiában és ezek oktatási vonatkozásai. Szaknyelv és szakfordítás. 13. (1) 27-33.

FÖLDVÁRI G. és DARAB K., (1966). Magyarország genetikus talajtípusainak, altípusainak és változatainak szisztematikus jegyzéke. In: A Genetikus Üzemi Talajtérképezés Módszerkönyve (szerk.: SzABOLCS I.). Országos Mezőgazdasági Minőségvizsgáló Intézet. Budapest.

IUSS WORKING GROUP WRB (2006) World Reference Base for Soil Resources, 2nd edition, World Soil Resources Reports no 103, UN Food and Agriculture Organization, Rome.

KāRklinš̌, A., Gemste, I., MežAls, H., Nikodemus, O. and Skujans, R. (2009) Latvijas augšnu noteicējs (Taxonomy of Latvian soils), LLU, Jelgava, (lett, angol összefoglalóval)

KrasilniKov, P., IBANEZ MARTI, J., ARNOLDS, R. and ShOBA, S. 2009. A handbook of soil terminology, correlation and classification.

MÉM (1989). (szerk. Jassó F., HoRváth B., IzSÓ I., KirÁly L., PARÁsZKa L. és SZABÓNÉ KELE G.). Útmutató a nagyméretarányú országos talajtérképezés végrehajtásához. Melioráció-öntözés és talajvédelem. Agroinform. Budapest.

Michéli E., Fuchs M., Szegi T., Csorba Á., Dobos E., SzABÓNÉ Kele G., (2018). A diagnosztikus szemléletben megújított hazai talajosztályozási rendszer: alapelvek, felépítés, osztályozási szabályok. Vitaanyag 2018.10.10. SZIE, Gödöllő. http:/talaj.hu/wp-content/uploads/2019/04/Hazai talajosztalyozasi_rendszerunk megujitasi javaslatai 20181010.pdf

Nestroy, O., Dannenberg, O. H., English, M., Gessl, A., Herzenberger, E., Kilian, W., Nelhiebel, P., Pecina, E., Pehamberger, A., Schneider, W. UND WAGNER, J. (2011). 'Systematische Gliederung der Boden Osterreichs (Osterreichische Bodensystematik 2000 in der revidierten Fassung von 2011)', Osterreichischen Bodenkundlichen Gesellschaft, Wien

То́тн G., (2019). Hazai talajosztályozási rendszerünk megújítási javaslatai (2018.10.10) - felkért referátum melléklete. http://talaj.hu/wp-content/uploads/2019/07/Felkert Referatum melleklete TothG.pdf

Open Access nyilatkozat: A cikk a Creative Commons Attribution 4.0 International License (https://creativecommons.org/licenses/by/4.0) feltételei szerint publikált Open Access közlemény, melynek szellemében a cikk bármilyen médiumban szabadon felhasználható, megosztható és újraközölhető, feltéve, hogy az eredeti szerző és a közlés helye, illetve a CC License linkje és az esetlegesen végrehajtott módosítások feltüntetésre kerülnek. (SID_1) 